\title{
Lusioersily
}

\section{Peptide YY (1-36) peptides from phylogenetically ancient fish targeting mammalian neuropeptide $Y 1$ receptors demonstrate potent effects on pancreatic $\beta$-cell function, growth and survival}

Lafferty, R., Tanday, N., Mc Closkey, A., Bompada, P., De Marinis, Y., Flatt, PR., \& Irwin, N. (2020). Peptide YY (1-36) peptides from phylogenetically ancient fish targeting mammalian neuropeptide $Y 1$ receptors demonstrate potent effects on pancreatic $\beta$-cell function, growth and survival. Diabetes, Obesity and Metabolism, 22(3), 404416. https://doi.org/10.1111/dom.13908

Link to publication record in Ulster University Research Portal

Published in:

Diabetes, Obesity and Metabolism

Publication Status:

Published (in print/issue): 31/03/2020

DOI:

10.1111/dom.13908

Document Version

Author Accepted version

\section{General rights}

Copyright for the publications made accessible via Ulster University's Research Portal is retained by the author(s) and / or other copyright owners and it is a condition of accessing these publications that users recognise and abide by the legal requirements associated with these rights.

\section{Take down policy}

The Research Portal is Ulster University's institutional repository that provides access to Ulster's research outputs. Every effort has been made to ensure that content in the Research Portal does not infringe any person's rights, or applicable UK laws. If you discover content in the Research Portal that you believe breaches copyright or violates any law, please contact pure-support@ulster.ac.uk. 
PYY(1-36) peptides from phylogenetically ancient fish targeting mammalian NPY1

receptors demonstrate potent effects on pancreatic beta-cell function, growth and survival

Ryan A. Lafferty ${ }^{1}$, Neil Tanday ${ }^{1}$, Andrew McCloskey ${ }^{1}$, Pradeep Bompada ${ }^{2}$, Yang De Marinis², Peter R. Flatt ${ }^{1}$, Nigel Irwin ${ }^{1 *}$

${ }^{1}$ SAAD Centre for Pharmacy and Diabetes, University of Ulster, Coleraine, Northern Ireland, BT52 1SA, UK

${ }^{2}$ Genomics, Diabetes and Endocrinology, Department of Clinical Sciences Malmö, Lund University, Malmö, Sweden

*Address correspondence and reprint requests to Dr Nigel Irwin, Diabetes Research Group, University of Ulster, Coleraine, Northern Ireland, BT52 1SA, UK

Email: n.irwin@ulster.ac.uk

Tel: ++44 (0) 2870124574

Fax: ++44 (0) 2870123939

Running title: Piscine-derived PYY(1-36)

This article has been accepted for publication and undergone full peer review but has not been through the copyediting, typesetting, pagination and proofreading process which may lead to differences between this version and the Version of Record. Please cite this article as doi: $10.1111 /$ dom.13908 


\begin{abstract}
Aim: Activation of neuropeptide Y1 receptors (NPYR1's) by the peptide hormone, Peptide YY (PYY), evokes benefits on pancreatic beta-cells. However, rapid N-terminal enzymatic cleavage of PYY in the circulation dramatically diminishes NPYR1 specificity. The aim of the current study was to investigate antidiabetic efficacy of enzymatically stable PYY peptides.

Materials and Methods: N-terminally stabilised, PYY(1-36) sequences from phylogenetically ancient fish, namely Amia calva (bowfin), Oncorhynchus mykiss (trout), Petromyzon marinus (sea lamprey) and Scaphirhynchus albus (sturgeon), were synthesised and both biological actions and antidiabetic therapeutic efficacy assessed.
\end{abstract}

Results: All fish PYY(1-36) peptides were resistant to dipeptidyl peptidase-4 (DPP-4) degradation and inhibited glucose- and alanine-induced $(\mathrm{P}<0.05$ to $\mathrm{P}<0.001)$ insulin secretion. In addition, $\mathrm{PYY}(1-36)$ peptides imparted significant $(\mathrm{P}<0.05$ to $\mathrm{P}<0.001)$ beta-cell proliferative and anti-apoptotic benefits. Proliferative effects were almost entirely absent in beta-cells with CRISPR-Cas9 induced knockout of Npyr1. In contrast to human PYY(1-36), the piscine-derived peptides lacked appetite suppressive actions. Twice daily administration of sea lamprey PYY(1-36), the superior bioactive peptide, for 21-days significantly ( $<<0.05$ to $\mathrm{P}<0.001$ ) decreased fluid intake, non-fasting glucose and glucagon in streptozotocin (STZ)induced diabetic mice. In addition, glucose tolerance, insulin sensitivity, pancreatic insulin and glucagon content were significantly improved. Metabolic benefits were linked to positive 
changes in pancreatic islet morphology, as a result of augmented $(\mathrm{P}<0.001)$ proliferation and decreased apoptosis of beta-cells. Sturgeon PYY(1-36) exerted similar but less impressive effects in STZ mice.

Conclusion: The current observations reveal, for the first time, that PYY(1-36) peptide sequences from phylogenetically ancient fish replicate the pancreatic beta-cell benefits of human PYY(1-36) and possess clear potential for the treatment of type 2 diabetes.

Keywords: Peptide YY (PYY); degradation; insulin secretion; beta-cell; appetite; bowfin; trout; sturgeon; lamprey

\section{Introduction}

Peptide Tyrosine Tyrosine (PYY), a gut-derived 36 amino acid residue peptide hormone, is released post-prandially from intestinal L-cells and imparts important effects on food intake and metabolism [2]. These biological actions are mediated through binding and interaction with neuropeptide Y receptors (NPYRs) [2]. PYY(1-36) is a full agonist for all human NPYR subtypes, namely NPY1, NPY2, NPY4 and NPY5 receptors [2,3]. However, rapidly after release into the circulation PYY(1-36) is degraded by the ubiquitous enzyme dipeptidyl peptidase-4 (DPP-4), to yield PYY(3-36) [4]. This N-terminal degradation dramatically alters the biological activity of PYY, since PYY(3-36) is a NPY2R-selective agonist, with negligible activity at other NPYRs [5]. Given knowledge of the appetite suppressive effects of hypothalamic NPYR2 activation [6], PYY(3-36) has been extensively studied as a potential 
anti-obesity drug [7-9]. Despite this, PYY(3-36) based drugs have yet to be exploited clinically, likely due to adverse gastrointestinal side-effects following administration in humans [10].

A more exciting area of PYY research in recent times relates to beneficial effects of PYY(1-36) at the level of the endocrine pancreas [11]. The NPYR1 is abundantly expressed on pancreatic beta-cells [12], with local islet synthesis and secretion of PYY(1-36) also noted [13]. Indeed, there is a suggestion that the impressive endocrine pancreatic benefits following Roux-en-Y gastric bypass (RYGB) surgery are linked to altered PYY secretion and enhanced NPYR1 activity [14]. As such, confirmed pancreatic effects of NPYR1 activation include inhibition of glucose-stimulated insulin secretion (GSIS) to induce beta-cell rest, as well as promoting growth and survival of beta-cells $[13,15]$. Since both major forms of diabetes mellitus, type 1 (T1DM) and type 2 (T2DM), are associated with beta-cell loss and/or dysfunction [16,17], agents mimicking the action of PYY(1-36) on pancreatic beta-cells could possess distinct therapeutic usefulness. Consequently, N-terminally stabilised PYY(1-36) peptide analogues, resistant to DPP-4 degradation to maintain NPYR1 activity, are of particular interest. A recent study has employed available PYY/NPYR1 structure/function knowledge in an attempt to generate enzymatically stable, NPYR1 specific, PYY(1-36) sequences [18]. However, the bioactivity of these chemically engineered PYY(1-36) peptides was less impressive than anticipated [18]. Consequently, there is still an imperative need to develop stabilised PYY(1-36) peptides, with NPYR1 specificity, as a possible new and effective class of antidiabetic therapeutics.

The NPY family of peptides arose via successive duplications of an ancestral gene, to produce the distinct genes that encode for pancreatic polypeptide (PP), neuropeptide Y (NPY) 
and PYY [19]. From evolutionary data, it has been established that the primary structure of PYY(1-36) is strongly conserved in fish [19]. Therefore, PYY(1-36) sequences from phylogenetically ancient fish may represent the most structurally ancient, highly conserved, PYY peptides in nature. For the present study, we sought to identify ancient fish PYY(1-36) sequences with inherent protection against DPP-4 activity, as naturally occurring NPYR1 specific PYY molecules. Computational and structural analyses revealed Amia calva (bowfin), Oncorhynchus mykiss (trout), Petromyzon marinus (sea lamprey) and Scaphirhynchus albus (sturgeon) PYY(1-36) as the most credible options in this regard. Initial studies examined enzymatic stability of these piscine PYY(1-36) sequences to purified DPP-4. In addition, effects on pancreatic beta-cell function, growth and survival were assessed, alongside NPYR1 and NPYR2 specificity. The impact of PYY(1-36) peptides on glucose homeostasis, insulin secretion and satiety were also investigated in vivo. Finally, we examined beneficial metabolic and related pancreatic architectural effects of twice-daily injection of the most promising piscine-derived peptides in streptozotocin (STZ)-induced diabetic mice. The data reveal, for the first time, that PYY(1-36) peptide sequences from phylogenetically ancient fish are metabolically stable and recapitulate in mammals the pancreatic beta-cell benefits of human PYY(1-36), with unmistakable therapeutic potential for type 2 diabetes.

\section{Materials and Methods}

\section{Peptides}

All peptides were supplied by Synpeptide Ltd (Shanghai, China) in excess of 95\% purity and characterised in-house by HPLC with MALDI-TOF (Table 1), as described previously [20]. 


\section{Degradation by DPP-4}

PYY(1-36) peptides $(50 \mu \mathrm{g})$ were incubated at $37^{\circ} \mathrm{C}$ on a plate-shaker in $50 \mathrm{mM}$ triethanolamine/HCl (pH 7.8) with $0.05 \mathrm{U}$ of purified DPP-4 (Sigma Aldrich) for 0 and 8 hours. Reactions were terminated by addition of $10 \mu \mathrm{l}$ of $10 \%(\mathrm{v} / \mathrm{v})$ trifluoroacetic acid/water. Reaction mixes were separated by RP-HPLC using a $(250 \times 4.6 \mathrm{~mm})$ Phenomenex C-18 analytical column, with absorbance monitored at $214 \mathrm{~nm}$ using a Thermoquest, SpectraSystem UV2000 detector. Defined HPLC peaks were collected and identified via MALDI-TOF MS on a PerSeptive Biosystems Voyager-DE Biospectrometer (Hertfordshire, UK), to corroborate peptide stability, as described previously [18].

\section{In vitro insulin secretion}

In vitro effects of PYY(1-36) peptides on insulin secretion were determined using rodent BRIN-BD11 beta-cells. The characteristics of this cell line, including glucose-sensitivity and insulin secretory function, have been described in detail previously [21]. Cells were cultured in RPMI 1640 media (Gibco Life Technologies Ltd), supplemented with 10\% v/v foetal bovine serum (Gibco), $1 \% \mathrm{v} / \mathrm{v}$ antibiotics $\left(0.1 \mathrm{mg} / \mathrm{ml}\right.$ streptomycin and $100 \mathrm{U} / \mathrm{ml}$ penicillin) at $37^{\circ} \mathrm{C}$ in $5 \%$ atmospheric $\mathrm{CO}_{2}$. For experimentation, cells were seeded into 24-well plates (Falcon Ltd) at a density of 150,000 cells per well. Following overnight attachment, media was aspirated and cells were pre-incubated in $1.1 \mathrm{mM}$ glucose KRB buffer for 40 minutes. Following removal of pre-incubation buffer, $1 \mathrm{ml}$ of KRB test solution, containing either 5.6 or 16.7 mM glucose with PYY(1-36) test peptides $\left(10^{-12}-10^{-6} \mathrm{M}\right)$ was added. In a second series 
of experiments, insulin secretory effects of PYY(1-36) peptides were determined following incubation in the presence of alanine $(10 \mathrm{mM})$ [18]. For all experiments, following a $20 \mathrm{~min}$ incubation period, supernatant was collected and stored at $-20^{\circ} \mathrm{C}$ until determination of insulin concentrations by a fully characterised dextran coated charcoal radioimmunoassay [22].

\section{Beta-cell proliferation and apoptosis}

To assess the effects of PYY $(1-36)$ peptides $\left(10^{-8}\right.$ and $\left.10^{-6} \mathrm{M}\right)$ on beta-cell proliferation and protection against apoptosis, rodent BRIN-BD11 and human 1.1B4 beta-cells [23] were used. Both hybrid cells lines were created using electrofusion technology of rodent or human islets and an appropriate immortal cell fusion partner [21,23]. Cells were seeded onto sterilised clearglass coverslips (16 mm diameter) and placed in 12-well plates (Falcon Ltd) at a density of 40,000 cells per well and cultured for $18 \mathrm{~h}$. Unsupplemented media, GLP-1 (10 ${ }^{-8}$ and $\left.10^{-6} \mathrm{M}\right)$ and a cytokine cocktail mix (IL-1 $\beta(100 \mathrm{U} / \mathrm{mL}), \operatorname{IFN} \gamma(20 \mathrm{U} / \mathrm{mL}), \mathrm{TNF} \alpha(200 \mathrm{U} / \mathrm{mL}))$ were employed as controls, as appropriate. Cells were subsequently rinsed with PBS and fixed using 4\% paraformaldehyde. After antigen retrieval with sodium citrate buffer at $95^{\circ} \mathrm{C}$ for $20 \mathrm{~min}$, blocking was performed using 2\% BSA for 45 min. For proliferation studies, the coverslips were incubated at $37^{\circ} \mathrm{C}$ with rabbit anti-Ki-67 primary antibody (Abcam, ab15580), and then with Alexa Fluor ${ }^{\circledR} 488$ secondary antibody. Coverslips were mounted onto polysine-coated microscope slides and mounted using a 50:50 Glycerol:PBS solution and stored at $4^{\circ} \mathrm{C}$ until required for analysis. To assess receptor selectivity, beta-cell proliferative effects of peptides were examined in an additional study using INS1 832/13 cells with CRISPR-Cas9 induced knockout (KO) of either the Npy1r or Npyr2. INS1 832/13 cells were chosen for these studies 
based on their superior transfection efficiency and increased secretory responsiveness when compared to BRIN BD11 or 1.1B4 cells. Details on generation and characterisation of both KO cell lines is available within the supplementary material. To determine the ability of PYY(1-36) peptides to protect against cytokine-induced apoptosis, BRIN BD11 and 1.1B4 cells were seeded, washed and fixed as above, with the exception that the media was supplemented with the cytokine mix. The coverslips were then incubated at $37^{\circ} \mathrm{C}$ with $\mathrm{TUNEL}$ reaction mix (Roche Diagnostics Ltd, UK) for $60 \mathrm{~min}$, and mounted onto microscope slides, as above. All slides were viewed using a fluorescent microscope (Olympus System Microscope, model BX51; Southend-on-Sea, UK) and photographed by DP70 camera adapter system. Proliferation/TUNEL positive frequency was determined using the cell-counter function on ImageJ Software and expressed as \% of total cells analysed, as described previously from our laboratory $[13,18]$.

\section{Animals}

Acute animal studies were performed using adult male NIH Swiss TO mice (12 weeks of age, Envigo Ltd, UK). Longer-term studies to assess antidiabetic efficacy were conducted in male NIH Swiss TO mice (14 weeks of age), with diabetes induced by multiple low dose streptozotocin (STZ) injection (4 h fast, 50 mg/kg bw, i.p., in sodium citrate buffer, pH 4.5), for 5 consecutive days. Once diabetes was established, animals were matched for body weight and blood glucose and recruited onto the study. An additional group of mice $(n=8)$ received saline instead of STZ injections. Mice were provided with standard rodent chow (10\% fat, 30\% protein and 60\% carbohydrate; Trouw Nutrition, Northwich, UK) and drinking water ad 
libitum. Mice were housed individually and kept in a temperature-controlled environment (22 $\pm 2^{\circ} \mathrm{C}$ ), with a 12 hour light/dark cycle. Experiments were carried out in accordance with the UK Animal Scientific Procedures Act 1986.

\section{Acute in vivo effects}

Acute effects of PYY(1-36) peptides on food intake were tested in overnight (18 h) fasted mice. Mice were administered an intraperitoneal (i.p.) injection of saline vehicle $(0.9 \%(\mathrm{w} / \mathrm{v}) \mathrm{NaCl})$ alone or in combination with test peptides (each at $25 \mathrm{nmol} / \mathrm{kg} \mathrm{bw}$ ) and cumulative food intake measured at regular intervals. Furthermore, effects of PYY(1-36) peptides on glucose homeostasis and insulin secretion were evaluated following i.p. injection of glucose alone (18 $\mathrm{mmol} / \mathrm{kg} \mathrm{bw}$ ) or in combination with test peptides (each at $25 \mathrm{nmol} / \mathrm{kg} \mathrm{bw}$ ) in overnight fasted mice.

\section{Sub-chronic in vivo effects}

Following recruitment into respective studies, diabetic NIH mice $(n=8)$ received twice-daily injections (09:00 and 17:00 h) of saline vehicle $(0.9 \%(\mathrm{w} / \mathrm{v}) \mathrm{NaCl})$ or test peptides (each at 25 $\mathrm{nmol} / \mathrm{kg}$ bw) for 21 days. Cumulative energy and fluid intake, body weight, circulating glucose and plasma insulin were assessed at regular intervals. At the end of the treatment period, glucose tolerance (18 mmol/kg bw; i.p.; $18 \mathrm{~h}$-fasted mice) and insulin sensitivity (25 U/kg bovine insulin; i.p.; non-fasted mice) tests were performed. Terminal analyses included extraction of pancreatic tissue with appropriate processing for measurement of hormone content following acid/ethanol protein extraction or determination of islet architecture, as 
described previously [13]. In addition, co-staining of insulin (1:500; Abcam, ab6995) or glucagon (PCA2/4, 1:200; raised in-house) with Ki-67 (1:400; Abcam ab15580) and TUNEL reaction mixture (Roche Diagnostics Ltd, UK) was used to assess beta-cell proliferation and apoptosis. Following incubation with primary antibodies, appropriate fluorescent secondary antibodies were employed (Table 2). Slides were viewed under a FITC (488 nm) or TRITC filter (594 nm), as appropriate, using a fluorescent microscope (Olympus system microscope, model BX51) and photographed using a DP70 camera adapter system. Islet parameters were analysed using Cell ${ }^{\mathrm{F}}$ image analysis software (Olympus Soft Imaging Solutions, GmbH).

\section{Biochemical analyses}

Blood samples were collected from the cut tip on the tail vein, of conscious mice, at times indicated in Figures 3-5. Blood glucose was measured immediately using a hand-held Ascencia Contour blood glucose meter (Bayer Healthcare, Newbury, Berkshire, UK). For plasma insulin, glucagon and C-reactive protein (CRP), blood was collected in chilled fluoride/heparin coated micro-centrifuge tubes (Sarstedt, Numbrecht, Germany) and centrifuged using a Beckman micro-centrifuge (Beckman Instruments, Galway, Ireland) for 10 minutes at 12,000 rpm. Plasma was separated and stored at $-20^{\circ} \mathrm{C}$, until determination of plasma insulin by radioimmunoassay [22] and glucagon or CRP by commercially available ELISA kits (EZGLU30K and RAB1121; respectively, Merck Millipore).

\section{Statistical analysis}


Statistical analyses were performed using GraphPad PRISM software (Version 5.0). Values are expressed as mean \pm S.E.M. Comparative analyses between groups were carried out using a One-way ANOVA with Bonferroni's post hoc test or student's unpaired t-test, as appropriate. The difference between groups was considered significant if $\mathrm{P}<0.05$.

\section{Results}

\section{In vitro DPP-4 stability}

As expected, incubation of human PYY(1-36) with DPP-4 for $8 \mathrm{~h}$ resulted in generation of the N-terminally cleaved product, PYY(3-36) (Table 1). In contrast, the fish PYY(1-36) peptides, namely bowfin, trout, sturgeon and sea lamprey, were completely resistant to DPP-4 mediated degradation over the $8 \mathrm{~h}$ period (Table 1 ).

\section{Effects of fish PYY(1-36) peptides on insulin secretion from BRIN BD11 beta-cells}

Human PYY(1-36), and all related piscine-derived PYY(1-36) peptides, significantly $(\mathrm{P}<0.05$ to $\mathrm{P}<0.001$ ) inhibited insulin secretion from BRIN BD11 cells at $5.6 \mathrm{mM}$ glucose at concentrations of $10^{-10} \mathrm{M}$ and above (Figure 1A). Interestingly, the PYY(1-36) sequences from phylogenetically ancient fish were more effective in this regard $(\mathrm{P}<0.05$ to $\mathrm{P}<0.001)$ compared with human PYY(1-36) at $10^{-7}$ and $10^{-6} \mathrm{M}$ (Figure 1A). Indeed, sea lamprey PYY(1-36) was significantly $(\mathrm{P}<0.05)$ more efficacious than human PYY(1-36) at $10^{-8} \mathrm{M}$ (Figure $\left.1 \mathrm{~A}\right)$. In a similar fashion, all PYY(1-36) peptides had insulinostatic actions at $16.7 \mathrm{mM}$ glucose, although only at concentrations of $10^{-7} \mathrm{M}$ and above for human PYY(1-36), whereas all piscine-derived peptides were effective at $10^{-11} \mathrm{M}$ (Figure 1B). Further to this, all PYY(1-36) peptides $\left(10^{-7}\right.$ 
and $\left.10^{-6} \mathrm{M}\right)$, barring bowfin $\mathrm{PYY}(1-36)$ at $10^{-7} \mathrm{M}$, inhibited $(\mathrm{P}<0.05-\mathrm{P}<0.001)$ alanineevoked elevations of insulin secretion (Figure 1C).

\section{Effects of fish PYY(1-36) peptides on beta-cell proliferation and protection against cytokine-induced apoptosis}

GLP-1, PYY(1-36) and all fish PYY(1-36) peptides imparted significant $(\mathrm{P}<0.05$ to $\mathrm{P}<0.001)$ protective effects against cytokine-induced apoptosis in both BRIN BD11 (Figure 2A) and 1.1 B4 (Figure 2B) beta-cells. In terms of proliferative actions, both human GLP-1 and PYY(1-36) $\left(10^{-8}\right.$ and $\left.10^{-6} \mathrm{M}\right)$ significantly $(\mathrm{P}<0.01$ to $\mathrm{P}<0.001)$ augmented BRIN BD11 and 1.1B4 betacell proliferation (Figure 2C,D). The fish PYY(1-36) peptides also possessed similar significant $(\mathrm{P}<0.05$ to $\mathrm{P}<0.001)$ beta-cell proliferative actions in both cell lines, with the exception of $10^{-8} \mathrm{M}$ sturgeon PYY(1-36) in BRIN BD11 cells and $10^{-8} \mathrm{M}$ trout PYY(1-36) in 1.1B4 cells (Figure 2C,D). To probe which NPY receptor is involved in mediating actions of PYY(1-36) peptides, beta-cell proliferative effects were examined in INS1 832/13 cells with Npy1r or Npy2r KO introduced by CRISPR-Cas9 (Figure 2E). As expected from observations in BRIN BD11 and 1.1B4 cells, GLP-1 and all PYY(1-36) peptides (at either $10^{-6}$ or $10^{-8} \mathrm{M}$ ) effectively ( $\mathrm{P}<0.05$ to $\mathrm{P}<0.01)$ promoted beta-cell proliferation in INS1 832/13 cells (Figure 2E). In Npy1r KO cells, all PYY(1-36) peptides were ineffective in terms of stimulating betacell growth, with the exception of trout PYY(1-36) at $10^{-6} \mathrm{M}$ (Figure 2E). All piscine PYY(136) peptides imparted beta-cell proliferative actions in Npy2r KO cells at concentrations of either $10^{-8}$ or $10^{-6} \mathrm{M}$ (Figure $2 \mathrm{E}$ ). 
Acute effects of fish PYY(1-36) peptides on food intake, glucose tolerance and insulin secretion in mice

Intraperitoneal administration of $25 \mathrm{nmol} / \mathrm{kg}$ human PYY(1-36) to overnight fasted mice induced a significant reduction $(\mathrm{P}<0.05$ to $\mathrm{P}<0.01$ ) in food intake at 120 minutes post injection (Figure 3A). None of the piscine PYY(1-36) peptides had appetite suppressive actions over the observation period (Figure 3A). Indeed, bowfin PYY(1-36) significantly $(\mathrm{P}<0.05$ to $\mathrm{P}<0.01$ ) increased food intake when compared to saline control mice at several time points (Figure 4). Moreover, all fish PYY(1-36) peptides, barring sturgeon PYY(1-36), increased ( $<<0.05$ to $\mathrm{P}<0.001)$ food intake when compared to human PYY(1-36) (Figure 3A). None of the PYY(136) peptides had any effect on glucose homeostasis or insulin secretion when administered in combination with glucose to mice (Figure 3B-E).

Sub-chronic effects of sea lamprey and sturgeon PYY(1-36) on body weight, food and fluid intake as well as circulating glucose, glucagon, insulin and CRP in STZ-induced diabetic mice

Based on the above results, sea lamprey and sturgeon PYY(1-36) were selected to examine sub-chronic beneficial effects in STZ-induced diabetic mice. There was a progressive loss of body weight in all STZ diabetic mice over the 21-day treatment period (Figure 4A). This body weight reduction was significantly $(\mathrm{P}<0.05)$ countered by sea lamprey or sturgeon PYY $(1-36)$ (Figure 4B). Cumulative food intake was increased $(\mathrm{P}<0.01$ to $\mathrm{P}<0.001)$ in STZ mice on days 18 and 21, and in sturgeon PYY $(1-36)$ mice $(\mathrm{P}<0.05)$ on day 21, when compared to lean controls (Figure 4C). Fluid intake was substantially $(\mathrm{P}<0.05$ to $\mathrm{P}<0.001)$ increased in saline 
and sturgeon PYY(1-36) treated STZ mice, but significantly $(\mathrm{P}<0.05$ to $\mathrm{P}<0.01)$ reduced in sea lamprey PYY(1-36) treated mice from day 9 onwards (Figure 4D). As would be expected, circulating glucose levels steadily increased $(\mathrm{P}<0.01$ to $\mathrm{P}<0.001)$ in control diabetic STZ mice, but were significantly ( $\mathrm{P}<0.05$ to $\mathrm{P}<0.001)$ decreased by sea lamprey PYY(1-36) from day 16 onwards (Figure 4E). Corresponding non-fasting plasma insulin concentrations were elevated $(\mathrm{P}<0.01$ to $\mathrm{P}<0.001)$ in sea lamprey treated mice from day 13 when compared to diabetic control mice (Figure 4F). Similar observations on circulating insulin were made in mice treated with sturgeon PYY(1-36), with the exception of day 21, where insulin concentrations were similar to saline control levels (Figure $4 \mathrm{~F})$. Circulating glucagon was significantly $(\mathrm{P}<0.01)$ reduced in sea lamprey and sturgeon PYY(1-36) treated STZ mice on day 21, with levels similar to those observed in lean control mice (Figure 4G). CRP concentrations were not different between groups of diabetic mice (data not shown).

\section{Sub-chronic effects of sea lamprey and sturgeon PYY(1-36) on glucose tolerance, peripheral insulin sensitivity as well as pancreatic insulin and glucagon content in STZ- induced diabetic mice}

During glucose tolerance tests on day 21, plasma glucose levels were significantly $(\mathrm{P}<0.05)$ reduced at 15, 30 and 90 min post-injection in mice treated twice daily with sea lamprey PYY(1-36) when compared with STZ diabetic controls (Figure 5A). Subsequent AUC analysis confirmed a significantly $(\mathrm{P}<0.01)$ reduced glycaemic excursion with sea lamprey PYY $(1-36)$ (Figure 5A). Sturgeon PYY(1-36) treatment had no impact on individual or overall glucose levels following a glucose challenge on day 21 (Figure 5A). Corresponding glucose-induced 
plasma insulin concentrations were elevated $(\mathrm{P}<0.05)$ at 30 min post glucose injection in both sea lamprey and sturgeon PYY(1-36) treated mice when compared to STZ controls (Figure 5B). However, only sea lamprey PYY $(1-36)$ treatment increased $(\mathrm{P}<0.05)$ the net insulin secretory response compared to diabetic control mice, but this was still reduced $(\mathrm{P}<0.001)$ when compared to lean controls (Figure 5B). The overall glucose-lowering action of exogenous insulin injection was significantly $(\mathrm{P}<0.05)$ enhanced in sea lamprey, but not sturgeon, PYY $(1-$ 36) treated mice when compared to STZ-induced diabetic controls (Figure 5C). Pancreatic insulin content was significantly elevated in both sea lamprey $(\mathrm{P}<0.001)$ and sturgeon $(\mathrm{P}<0.05)$ treated mice when compared to STZ diabetic controls (Figure 5D). Corresponding pancreatic glucagon content was elevated $(\mathrm{P}<0.001)$ in STZ mice, but significantly $(\mathrm{P}<0.001)$ reduced by sea lamprey PYY(1-36) treatment (Figure 5E).

\section{Sub-chronic effects of sea lamprey and sturgeon PYY(1-36) on pancreatic morphology in STZ-induced diabetic mice}

Clear abnormalities of pancreatic morphology were evident in STZ diabetic mice including appearance of more centrally located glucagon-stained cells (Figure 6A-D). Quantitative evaluation confirmed this in saline $(\mathrm{P}<0.001)$ and sturgeon PYY $(1-36)(\mathrm{P}<0.05)$ treated STZ mice, whereas sea lamprey PYY $(1-36)$ treated mice had reduced $(\mathrm{P}<0.001)$ appearance of centrally located alpha-cells, and similar to lean control mice (Figure 6E). The number of pancreatic islets was not significantly different in sea lamprey PYY(1-36) treated STZ and lean control mice, whereas STZ and sturgeon PYY $(1-36)$ treated mice had reduced $(\mathrm{P}<0.001)$ islet numbers (Figure 6F). Interestingly, overall islet area was decreased $(\mathrm{P}<0.01)$ with sea lamprey 
PYY(1-36) treatment when compared to lean controls (Figure 6G), which could be related to the decreased $(\mathrm{P}<0.001)$ percentage of alpha cell area in these mice (Figure $6 \mathrm{H})$. Percentage beta-cell area was decreased $(\mathrm{P}<0.001)$ in all STZ mice compared to lean controls, but elevated $(\mathrm{P}<0.01)$ in sea lamprey PYY(1-36) mice when compared to STZ diabetic controls (Figure 6I). In keeping with this, proliferating and apoptotic beta-cells were significantly $(\mathrm{P}<0.001)$ increased and decreased, respectively, in sea lamprey PYY(1-36) treated mice when compared to diabetic controls, and not significantly different from lean mice (Figure 6J,K). Whilst the percentage of proliferating alpha-cells was not different between the various groups of mice (Figure 6L), sea lamprey PYY $(1-36)$ treatment significantly $(\mathrm{P}<0.05)$ reduced alpha-cell apoptosis although levels were still elevated $(\mathrm{P}<0.01)$ when compared to lean control mice (Figure 6M). Sturgeon PYY(1-36) treatment had no effect on alpha- and beta-cell area, or the number of proliferating and apoptotic alpha- or beta-cells when compared to STZ controls (Figure 6H-M). Representative images from each treatment group showing insulin and glucagon positive islet cells, co-stained with Ki-67 or TUNEL, are provided in the supplementary material.

\section{Discussion}

The difficulties in developing an enzymatically stable, NPYR1 specific, PYY(1-36) analogue based on current structure/function knowledge for PYY(1-36) have recently been highlighted [18]. In brief, a PYY(1-36) peptide analogue adopting the key characteristics known to enhance NPYR1 interaction, namely substitution of $\mathrm{Val}^{31}$ for $\mathrm{Leu}^{31}$ and $\mathrm{Gln}^{34}$ for $\mathrm{Pro}^{34}$ [24], exhibited noticeably diminished bioactivity at the level of the pancreatic beta cell [18]. To date, the only 
other description of a stable PYY analogue with some reported NPYR1 activity, named XPYY [25], is based on the sequence of PYY(3-36) that is considered to be a highly specific NPYR2 agonist [5].

We have previously successfully exploited highly conserved amino acid sequences from phylogenetically ancient fish in the search for naturally occurring, enzymatically stabilised, peptide hormone receptor agonists; including glucagon and GLP-1 [26-29]. The primary structures of bowfin, sea lamprey, sturgeon and trout PYY(1-36) peptides are depicted in Table 1, and compared to human PYY(1-36) and NPY, since these are established NPYR1 agonists [30]. It is apparent that the entire C-terminal segment, from residues 23-36, of all fish PYY(1-36) peptide sequences is highly conserved between human PYY and NPY. This is of considerable importance given that the C-terminus of the NPY family of peptides is fundamentally important for NPYR1 binding [31]. Although all piscine PYY(1-36) peptides have insertion of an Ile residue at positions 28 and 31, which is different to human PYY(1-36), such changes directly correspond to the human NPY sequence. More remarkably, $\mathrm{Ile}^{28}$ and $\mathrm{Ile}^{31}$ have been shown to be important for conservation of peptide helical structure and NPYR1 interaction [32]. A similar $\mathrm{Ala}^{23}$ for $\mathrm{Ser}^{23}$ substitution in the piscine sequences has also been noted to stabilise helical structure and enhance NPYR1 binding capacity [33-35]. The $\mathrm{Val}^{24}$ for $\mathrm{Leu}^{24}$ substitution in sea lamprey PYY(1-36) represents removal of a single methylene group, and likely to have minor implications on overall peptide conformation [36].

Moreover, when peptide sequences are studied in more detail, for bowfin PYY(1-36) the only non-conserved residue when compared to the sequences of human NPY and PYY is Pro ${ }^{3}$. For trout PYY(1-36), in addition to the Pro ${ }^{3}$ change, there are also $\mathrm{Lys}^{19}$ for $\mathrm{Arg}^{19}$ and 
$\mathrm{Thr}^{22}$ for Ser ${ }^{22}$ substitutions, representing replacements with amino acids that possess the same charge or polarity, respectively. The additional amino acid substitutions within sea lamprey and sturgeon PYY(1-36) provide less obvious intimations to structure/function, perhaps barring the similar negative charge of $\mathrm{Asp}^{10}$ and $\mathrm{Glu}^{10}$ in sturgeon and human PYY, respectively. Further important structure/function knowledge relating to the NPY family of peptides concerns the characteristic 'PP-fold' conformation [37], responsible for bringing the $\mathrm{N}$ - and the C-terminal ends of the peptide in close contact to be recognised by the NPYR1 [38]. This PP-fold is characterised by the poly-proline N-terminal segment, Pro $^{2}-$ Pro $^{5}-$ Pro $^{8}$, stabilised by a Pro residue situated either at position 13 or 14 and folded back on a long amphipathic $\alpha$-helix interacting with $\mathrm{Tyr}^{20}$ and $\mathrm{Tyr}^{27}$ [38]. Notably these residues are all conserved across the four piscine PYY(1-36) sequences. Taken together, the fundamental structural characteristics necessary for specific human NPYR1 binding and activation are present within bowfin, sea lamprey, sturgeon and trout PYY(1-36) peptide sequences.

In full agreement, the present study has demonstrated that PYY(1-36) peptides from these phylogenetically ancient fish possess similar bioactivity as human PYY(1-36) in the current mammalian test systems. All PYY(1-36) peptides inhibited both glucose- and alanineinduced insulin secretion, whilst encouraging beta-cell growth and protecting against apoptosis $[13,18]$. There were some slight differences in potency and efficacy, possibly indicating enhanced NPYR1 specificity of the piscine-derived peptides. In relation to this, human PYY(136) is subject to DPP-4 mediated, N-terminal dipeptide cleavage, generating a PYY(3-36) metabolite with dramatically reduced NPYR1 selectivity [4]. It has already been established that substitution with a proline residue at position three in human PYY(1-36) renders the 
peptide resistant to DPP-4 [18]. This is similar to observations with other DPP-4 liable peptide hormones, such as GIP and GLP-1 [39,40]. All piscine PYY(1-36) sequences contain a naturally occurring Pro $^{3}$ residue, and as expected, were enzymatically stable. To examine NPYR1 specificity in more detail, beta-cell proliferative effects of the PYY(1-36) peptides were examined in INS1 832/13 cells [41], with either Npy1r or Npy2r KO. In Npy1r KO cells, all PYY(1-36) peptides were ineffective in terms of stimulating beta-cell growth, with the exception of trout PYY(1-36) at the highest concentration tested, whereas all PYY(1-36) peptides displayed bioactivity in Npy2r KO cells. Therefore, the biological actions of trout PYY(1-36) may not be confined solely to interaction with NPYR1, unlike the other piscine peptides. Dual receptor activation properties of phylogenetically ancient fish peptides has been documented previously [26,29], and this could be of importance here.

In keeping with preserved NPYR1 activity of the fish derived peptides, appetite stimulatory effects of all peptides, barring sturgeon PYY(1-36), was observed when compared to human PYY(1-36). Notably, the increase in food intake by the piscine-derived PYY(1-36) peptides was only relative to human PYY(1-36). As such, none of the fish PYY(1-36) peptides increased food intake above saline control at the end of the observation period. Metabolism of human PYY(1-36) to PYY(3-36) in vivo results in appetite suppressive effects linked to NPYR2 activation [1,42], which would not occur with the piscine peptides. In agreement with limited acute insulinotropic or glucose homeostatic actions of PYY(1-36) [18], none of the peptides influenced glucose clearance or circulating plasma insulin when injected concurrently with glucose to mice. Based on these in vitro and in vivo studies, sturgeon and sea lamprey PYY(1-36) were selected to examine effects of sub-chronic twice daily administration in 
insulin-deficient STZ-diabetic mice. As such, sturgeon, and especially sea lamprey, PYY(136) partially corrected the characteristic weight loss, as well as increased water and food intake, in insulin-deficient STZ-diabetic mice [43]. The exact explanation as to why sea lamprey was more effective than sturgeon PYY is not obvious, especially given their similar in vitro biological action profiles, but could be related to differences in receptor binding kinetics or peptide half-lives, that requires further detailed study. However, benefits of the peptides were associated with improved glycaemic control, glucose tolerance, insulin sensitivity and, importantly, elevated plasma and pancreatic insulin concentrations with reduced plasma and pancreatic glucagon in sea lamprey treated mice. Interestingly, PYY peptides are not considered to directly modulate glucagon secretion, suggesting indirect effects on alpha-cells via surrounding beta- or delta-cells [44]. However, the ability of sea lamprey PYY to restore both disturbed insulin and glucagon levels in diabetes is of significant clinical relevance. Thus, acute administration of NPYR1 specific peptides is associated with insulinostatic actions and beta-cell rest [13], whereas prolonged activation of beta-cell NPYR1's promotes cell growth and survival, leading to significant elevations in basal and glucose-stimulated insulin concentrations [15]. Plasma CRP levels were unchanged indicating lack of adverse inflammatory responses to fish peptides.

Consistent with metabolic benefits in STZ mice, beta-cell proliferation was enhanced and apoptosis decreased, by sea lamprey PYY(1-36) treatment. Thus, beta-cell area was increased, despite a marginal reduction overall islet area. Such observations directly correlate with knowledge that the notable pancreatic benefits of RYGB surgery are strongly linked to NPYR1 activation [14], alongside the recognised beta-cell pro-survival effects of PYY 
peptides [18]. Moreover, selective KO of PYY expressing cells in mice results in hyperglycaemia, as a direct result of increased beta-cell destruction [25]. In addition, STZinduced insulin deficiency has been shown to decrease islet PYY expression [13]. Interestingly, the characteristic infiltration of glucagon positively stained central islet cells induced by STZ injection in mice [45] was reversed by sea lamprey PYY(1-36) treatment. Indeed, apoptotic rate of pancreatic alpha-cells was decreased by sea lamprey PYY(1-36) and proliferation unchanged, yet alpha-cell area and pancreatic glucagon content declined, implying strong likelihood of lineage transition of these cells. Given that PYY has an established role in early pancreatic islet cell development in utero [46], positive effects of sea lamprey PYY(1-36) on pancreatic islet cell plasticity and lineage reprograming would seem credible, but requires further detailed study.

In conclusion, the present study has demonstrated that PYY(1-36) peptide sequences from phylogenetically ancient fish represent enzymatically stable, human NPYR1 modulators. The highly beneficial beta-cell effects of chronic NPYR1 activation [15] was exemplified by sea lamprey PYY(1-36) treatment in STZ-induced insulin deficient mice, and importantly lacked any proinflammatory effects. Further studies are required to assess the time-course of these effects and relative contribution of beta-cell regeneration and beta-cell protection/recovery (both stimulated by PYY) to the final improved beta-cell mass and glucose response in the mice. However, notable improvements in islet morphology and insulin secretion induced by sea lamprey PYY(1-36) represents the first credible evidence that stable peptide analogues acting at NPYR1 can offer a novel and effective treatment option for diabetes. 


\section{Conflict of interest}

PRF and NI are named on patents filed by the University of Ulster for exploitation of peptide therapeutics.

\section{Acknowledgments}

This work was supported by a PhD studentship (awarded to RAL) from the Department for the

Economy (DfE) Northern Ireland, an Invest Northern Ireland Proof of Concept grant and University of Ulster strategic research funding. YDM and PB were supported by the Swedish

Research Council, Strategic Research Area Exodiab, Dnr 2009-1039; and the Swedish Foundation for Strategic Research Dnr IRC15-0067; a European Foundation for the Study of Diabetes (EFSD) grant and Hjelt Foundation grant.

\section{References}

1. Chen CH \& Rogers RC, Central inhibitory action of peptide YY on gastric motility in rats. Am J Physiol. 1995; 269: 787-792.

2. Walther C, Mörl K, Beck-Sickinger AG. Neuropeptide Y receptors: Ligand binding and trafficking suggest novel approaches in drug development. J. Pept. Sci. 2011; 17: 233-246.

3. Keire DA, Bowers CW, Solomon TE, Reeve JR. Structure and receptor binding of PYY analogs. Peptides 2002; 23: 305-321.

4. Michel MC, Fliers E, Van Noorden CJF. Dipeptidyl peptidase IV inhibitors in diabetes: More than inhibition of glucagon-like peptide-1 metabolism. Naunyn. Schmiedebergs. Arch. Pharmacol. 2008; 377: 205-207.

5. Wu T, Rayner CK, Young RL, Horowitz M, Gut motility and enteroendocrine secretion. Curr. Opin. Pharmacol. 2013; 13: 928-934.

6. Batterham RL, Cowley MA, Small CJ, Herzog H, Cohen MA, Dakin CL, Wren AM, Brynes AE, Low MJ, Ghatei MA, Cone RD, Bloom SR. Gut hormone PYY3-36 physiologically inhibits food intake. Nature 2002; 418: 650-654.

7. Koegler FH, Enriori PJ, Billes SK, Takahashi DL, Martin MS, Clark RL, Evans AE, Grove KL, Cameron JL, Cowley MA. Peptide YY(3-36) inhibits morning, but not evening, food intake and decreases body weight in rhesus macaques. Diabetes 2005; 54: 3198-3204. 
8. Rangwala SM, D'Aquino K, Zhang YM, Bader L, Edwards W, Zheng S, Eckardt A, Lacombe A, Pick R, Moreno V, Kang L, Jian W, Arnoult E, Case M, Jenkinson C, Chi E, Swanson RV, Kievit P, Grove K, Macielag M, Erion MD, SinhaRoy R, Leonard JN. A Long-Acting PYY3-36 Analog Mediates Robust Anorectic Efficacy with Minimal Emesis in Nonhuman Primates. Cell Metab. 2019; 29: 837-843.

9. Sloth B, Holst JJ, Flint A, Gregersen NT, Astrup A. Effects of PYY1-36 and PYY3-36 on appetite, energy intake, energy expenditure, glucose and fat metabolism in obese and lean subjects. Am J Physiol Endocrinol Metab. 2007; 292: E1062-1068.

10. Schmidt JB, Gregersen NT, Pedersen SD, Arentoft JL, Ritz C, Schwartz TW, Holst JJ, Astrup A, Sjödin A. Effects of PYY3-36 and GLP-1 on energy intake, energy expenditure, and appetite in overweight men. Am. J. Physiol. Endocrinol. Metab. 2014; 306: 1248-1256.

11. Persaud SJ, Bewick GA. Peptide YY: more than just an appetite regulator. Diabetologia 2014; 57: 1762-1769.

12. Loh K, Shi YC, Bensellam M, Lee K, Laybutt DR, Herzog H. Y1 receptor deficiency in $\beta$-cells leads to increased adiposity and impaired glucose metabolism. Sci. Rep. 2018; 8: 11835.

13. Khan D, Vasu S, Moffett RC, Irwin N, Flatt PR. Islet distribution of Peptide YY and its regulatory role in primary mouse islets and immortalised rodent and human betacell function and survival. Mol Cell Endocrinol. 2016; 436: 102-113.

14. Ramracheya RD, McCulloch LJ, Clark A, Wiggins D, Johannessen H, Olsen MK, Cai $\mathrm{X}$, Zhao CM, Chen D, Rorsman P. PYY-Dependent Restoration of Impaired Insulin and Glucagon Secretion in Type 2 Diabetes following Roux-En-Y Gastric Bypass Surgery. Cell Rep. 2016; 15: 944-950.

15. Lafferty RA, Flatt PR, Irwin N. Emerging therapeutic potential for peptide YY for obesity-diabetes. Peptides 2018; 100: 269-274.

16. Donath MY, Ehses JA, Maedler K, Schumann DM, Ellingsgaard H, Eppler E, Reinecke M. Mechanisms of beta-cell death in type 2 diabetes. Diabetes 2005; 54: 108-113.

17. Herold KC, Usmani-Brown S, Ghazi T, Lebastchi J, Beam CA, Bellin MD, Ledizet M, Sosenko JM, Krischer JP, Palmer JP. $\beta$ cell death and dysfunction during type 1 diabetes development in at-risk individuals. J Clin Invest. 2015; 125: 1163-1173.

18. Lafferty RA, Gault VA, Flatt PR, Irwin N. Effects of two novel PYY(1-36) analogues, $\left(\mathrm{P}^{3} \mathrm{~L}^{31} \mathrm{P}^{34}\right) \mathrm{PYY}(1-36)$ and PYY(1-36)(Lys $\left.{ }^{12} \mathrm{PAL}\right)$, on pancreatic beta-cell function, growth and survival. Clin. Med. Insights. 2019; 12: 1-8.

19. Conlon JM. The origin and evolution of peptide YY (PYY) and pancreatic polypeptide (PP). Peptides 2002; 23: 269-278.

20. Pathak V, Vasu S, Gault VA, Flatt PR, Irwin N. Sequential induction of beta cell rest and stimulation using stable GIP inhibitor and GLP-1 mimetic peptides improves metabolic control in C57BL/KsJ db/db mice. Diabetologia 2015; 58: 2144-2153.

21. McClenaghan N, Barnett C, Ah-Sing E, Abdel-Wahab Y, O’Harte F, Yoon T, Swanston-Flatt S, Flatt PR. Characterisation of a novel glucose-responsive insulinsecreting cell line, BRIN-BD11, produced by electrofusion. Diabetes 1996; 45: 11321140. 
22. Flatt PR \& Bailey CJ. Plasma glucose and insulin response to glucagon and arginine in Aston ob/ob mice: evidence for a selective defect in glucose-mediated insulin release. Horm. Metab, Res. 1982; 3: 127-30.

23. McCluskey JT, Hamid M, Guo-Parke H, McClenaghan NH, Gomis R, Flatt PR. Development and functional characterization of insulin-releasing human pancreatic beta cell lines produced by electrofusion. J Biol Chem. 2011; 286: 21982-21992.

24. Söll RM, Dinger MC, Lundell I, Larhammer D, Beck-Sickinger AG. Novel analogues of neuropeptide Y with a preference for the Y1-receptor. Eur J Biochem. 2001; 268: 2828-2837.

25. Sam AH, Gunner DJ, King A, Persaud SJ, Brooks L, Hostomska K, Ford HE, Liu B, Ghatei MA, Bloom SR, Bewick GA. Selective ablation of peptide YY cells in adult mice reveals their role in beta cell survival. Gastroenterology 2012; 143: 459-68.

26. O'Harte FPM, Ng MT, Lynch AM, Conlon JM, Flatt PR. Novel dual agonist peptide analogues derived from dogfish glucagon show promising in vitro insulin releasing actions and antihyperglycaemic activity in mice. Mol. Cell. Endocrinol. 2016; 431: 133-144.

27. O'Harte FPM, Ng MT, Lynch AM, Conlon JM, Flatt PR. Dogfish glucagon analogues counter hyperglycaemia and enhance both insulin secretion and action in diet-induced obese diabetic mice. Diabetes Obes. Metabol. 2016; 18: 1013-1024.

28. Graham GV, Conlon JM, Abdel-Wahab YH, Gault VA, Flatt PR. Evaluation of the insulinotropic and glucose-lowering actions of zebrafish GIP in mammalian systems: Evidence for involvement of the GLP-1 receptor. Peptides 2018; 100: 182-189.

29. Graham GV, Conlon JM, Abdel-Wahab YH, Flatt PR. Glucagon-like peptides-1 from phylogenetically ancient fish show potent anti-diabetic activities by acting as dual GLP1R and GCGR agonists. Mol. Cell. Endocrinol. 2019; 480: 54-64.

30. Smith-White M, Moriarty MJ, Potter EK. A comparison of actions of neuropeptide Y (NPY) agonists and antagonists at NPY Y1 and Y2 receptors in anaesthetized rats. Neuropeptides 1998; 32: 109-18.

31. Beck-Sickinger AG, Wieland HA, Wittneben H, Willim KD, Rudolf K, Jung G. Complete L-alanine scan of neuropeptide Y reveals ligands binding to Y1 and Y2 receptors with distinguished conformations. Eur J Biochem. 1994; 225: 947-958.

32. Dyck $M$, Lösche $M$. Interaction of the neurotransmitter, neuropeptide $Y$, with phospholipid membranes: film balance and fluorescence microscopy studies. J Phys Chem B. 2006; 110: 22143-22151.

33. Barden JA. Structure of prejunctional receptor binding analog of human neuropeptide Y dimer ANA-NPY. Biochem Biophys Res Commun. 1995; 215: 264-271.

34. Potter EK, Mitchell L, McCloskey MJ, Tseng A, Goodman AE, Shine J, McCloskey DI. Pre- and postjunctional actions of neuropeptide Y and related peptides. Regul Pept. 1989; 25: 167-177.

35. Potter EK, Barden JA, McCloskey MJ, Selbie LA, Tseng A, Herzog H, Shine J. A novel neuropeptide $\mathrm{Y}$ analog, N-acetyl [Leu28,Leu31]neuropeptide Y-(24-36), with functional specificity for the presynaptic (Y2) receptor. Eur J Pharmacol. 1994; 267: 253-62. 
36. Keire DA, Mannon P, Kobayashi M, Walsh JH, Solomon TE, Reeve JR. Primary structures of PYY, [Pro34]PYY, and PYY-(3-36) confer different conformations and receptor selectivity. Am. J. Physiol. Gastrointest. Liver Physiol. 2000; 279: G126G131.

37. Germain N, Minnion JS, Tan T, Shillito J, Gibbard C, Ghatei M, Bloom S. Analogs of pancreatic polypeptide and peptide YY with a locked PP-fold structure are biologically active. Peptides 2013; 39: 6-10.

38. Nygaard R, Nielbo S, Schwartz TW, Poulsen FM. The PP-fold solution structure of human polypeptide YY and human PYY3-36 as determined by NMR. Biochemistry 2006; 45: 8350-8357.

39. Gault VA, O’Harte FPM, Harriott P, Flatt PR. Characterization of the cellular and metabolic effects of a novel enzyme-resistant antagonist of glucose-dependent insulinotropic polypeptide. Biochem Biophys Res Commun. 2002; 290: 1420-1426.

40. Green BD, Gault VA, Mooney MH, Irwin N, Bailey CJ, Harriott P, Greer B, Flatt PR, O'Harte FP. Novel dipeptidyl peptidase IV resistant analogues of glucagon-like peptide-1(7-36)amide have preserved biological activities in vitro conferring improved glucose-lowering action in vivo. J Mol Endocrinol. 2003; 31: 529-540.

41. Hohmeier HE, Mulder H, Chen G, Henkel-Rieger R, Prentki M, Newgard CB. Isolation of INS-1-derived cell lines with robust ATP-sensitive $\mathrm{K}+$ channel-dependent and independent glucose-stimulated insulin secretion. Diabetes 2000; 49: 424-30.

42. Pittner RA, Moore CX, Bhavsar SP, Gedulin BR, Smith PA, Jodka CM, Parkes DG, Paterniti JR, Srivastava VP, Young AA. Effects of PYY[3-36] in rodent models of diabetes and obesity. Int. J. Obes. Relat. Metab. Disord. 2004; 28: 963-971.

43. Irwin N, Pathak V, Pathak NM, Gault VA, Flatt PR. Sustained treatment with a stable long-acting oxyntomodulin analogue improves metabolic control and islet morphology in an experimental model of type 1 diabetes. Diabetes Obes Metab. 2015; 17: 887-95.

44. Guida C, Stephen S, Guitton R, Ramracheya RD. The Role of PYY in Pancreatic Islet Physiology and Surgical Control of Diabetes. Trends Endocrinol. Metab. 2017; 28: 626-636.

45. Li Z, Karlsson FA, Sandler S. Islet loss and alpha cell expansion in type 1 diabetes induced by multiple low-dose streptozotocin administration in mice. J Endocrinol. 2000; 165: 93-9.

46. H. Mulder, U. Myrsén-Axcrona, S. Gebre-Medhin, E. Ekblad, F. Sundler, Expression of non-classical islet hormone-like peptides during the embryonic development of the pancreas. Microsc. Res. Tech. 1998; 43: 313-321. 
Table 1. Amino acid sequences, expected and calculated masses as well as purity and DPP-4 stability for NPY and PYY(1-36) peptides

\begin{tabular}{|c|c|c|c|c|c|c|}
\hline Peptide & Amino Acid Sequence & $\begin{array}{c}\text { Sequence } \\
\text { homology (\%) }\end{array}$ & $\begin{array}{l}\text { Expected } \\
\text { Mass (Da) }\end{array}$ & $\begin{array}{l}\text { Calculated } \\
\text { Mass (Da) }\end{array}$ & $\begin{array}{l}\text { Peptide } \\
\text { purity }\end{array}$ & $\begin{array}{c}\text { \% DPP-4 } \\
\text { degradation } \\
\text { at } 8 \mathrm{~h}\end{array}$ \\
\hline Human NPY(1-36) & $\begin{array}{l}\text { Y-P-S-K-P-D-N-P-G-E-D-A-P-A-E-D-M-A-R- } \\
\text { Y-Y-S-A-L-R-H-Y-I-N-L-I-R-Q-R-Y- NH }\end{array}$ & - & 4271.7 & ND & ND & ND \\
\hline Human PYY(1-36) & $\begin{array}{l}\text { Y-P-I-K-P-E-A-P-G-E-D-A-S-P-E-E-L-N-R-Y- } \\
\text { Y-A-S-L-R-H-Y-L-N-L-V-T-R-Q-R-Y- } \mathrm{NH}_{2}\end{array}$ & - & 4309.8 & 4309.7 & 96.8 & 72.5 \\
\hline Bowfin PYY(1-36) & $\begin{array}{l}\text { Y-P-P-K-P-E- } N \text {-P-G-E-D-A-P-P-E-E-L- } A-\mathbf{R}- \\
\text { Y-Y-S-A-L-R-H-Y-I-N-L-I-T-R-Q-R-Y - } \mathrm{NH}_{2}\end{array}$ & 77.8 & 4317.8 & 4317.5 & 98.3 & 0 \\
\hline Trout PYY(1-36) & $\begin{array}{l}\text { Y-P-P-K-P-E- } N-P-G-E-D-A-P-P-E-E-L-A-K- \\
\text { Y-Y-T-A-L-R-H-Y-I-N-L-I-T-R-Q-R-Y - NH }{ }_{2}\end{array}$ & 75.0 & 4303.9 & 4303.6 & 95.9 & 0 \\
\hline $\begin{array}{c}\text { Sturgeon } \\
\text { PYY(1-36) }\end{array}$ & $\begin{array}{l}\text { F-P-P-K-P-E-H-P-G-D-D-A-P-A-E-D-V-V-K- } \\
\text { Y-Y-T-A-L-R-H-Y-I-N-L-I-T-R-Q-R-Y- NH }{ }_{2}\end{array}$ & 61.1 & 4270.8 & 4270.4 & 96.2 & 0 \\
\hline $\begin{array}{l}\text { Sea Lamprey } \\
\text { PYY(1-36) }\end{array}$ & $\begin{array}{l}\text { M-P-P-K-P-D- } N-\mathbf{P}-\mathrm{S}-\mathrm{P}-\mathrm{D}-\mathrm{A}-\mathrm{S}-\mathrm{P}-\mathrm{E}-\mathrm{E}-\mathrm{L}-\mathrm{S}-\mathrm{K}- \\
\text { Y-M-L-A-V-R-N-Y-I-N-L-I-T-R-Q-R-Y- } \mathrm{NH}_{2}\end{array}$ & 61.1 & 4285.9 & 4284.2 & 98.5 & 0 \\
\hline
\end{tabular}

Amino acids in bold text are conserved in human PYY(1-36). Amino acids in italic underlined text correspond to human NPY(1-36). Peptide masses were calculated using MALDI-TOF MS on a PerSeptive Biosystems Voyager-DE Biospectrometer. Peptide purity was assessed by HPLC and analysis of AUC data. For DPP-4 degradation, peptides $(50 \mu \mathrm{g})$ were incubated at $37^{\circ} \mathrm{C}$ in $50 \mathrm{mM}$ triethanolamine/ $\mathrm{HCl}$ with DPP-4 $(0.05 \mathrm{U})$ for 0 and 8 hours. Defined HPLC peaks were collected and identified via MALDI-TOF MS on a PerSeptive Biosystems Voyager-DE Biospectrometer. ND, not determined. 
Table 2. Target, host and source of primary and secondary antibodies employed for immunoflourescent islet histology and immunocytochemistry studies

\begin{tabular}{|c|c|c|c|c|}
\hline \multicolumn{2}{|c|}{ Primary antibodies } \\
\hline Target & Host & \multicolumn{2}{c|}{ Dilution } & Source \\
\hline Insulin & Mouse & \multicolumn{2}{|c|}{$1: 500$} & Abcam, ab6995 \\
\hline Glucagon & Guinea pig & \multicolumn{2}{|c|}{$1: 200$} & Abcam, ab15580 \\
\hline Ki-67 & Rabbit & \multicolumn{2}{|c|}{$1: 400$} & Fluorescent dye and source \\
\hline & & \multicolumn{2}{|c|}{ Secondary antibodies } \\
\hline Target & Host & Reactivity & Dilution & Alexa Fluor ${ }^{\circledR}$ 594, Invitrogen, UK \\
\hline IgG & Goat & Mouse & $1: 400$ & Alexa Fluor ${ }^{\circledR}$ 488, Invitrogen, UK \\
\hline IgG & Goat & Guinea pig & $1: 400$ & Alexa Fluor ${ }^{\circledR}$ 594, Invitrogen, UK \\
\hline IgG & Goat & Guinea pig & $1: 400$ & Alexa Fluor ${ }^{\circledR}$ 488, Invitrogen, UK \\
\hline IgG & Goat & Rabbit & $1: 400$ &
\end{tabular}




\section{Figure legends}

Figure 1. Effects of PYY(1-36) peptides on insulin release from rodent BRIN-BD11 betacells. BRIN BD11 cells were incubated with (A) 5.6, (B) $16.7 \mathrm{mM}$ glucose or (C) $16.7 \mathrm{mM}$ glucose supplemented with alanine $(10 \mathrm{mM})$ and the effects of PYY peptides $\left(10^{-6}-10^{-12} \mathrm{M}\right)$ on insulin secretion determined. Values are mean \pm SEM $(\mathrm{n}=8) .{ }^{*} \mathrm{P}<0.05,{ }^{*} * \mathrm{P}<0.01$, ****P $<0.001$ compared to respective glucose control. ${ }^{\Delta} \mathrm{P}<0.05,{ }^{\Delta \Delta} \mathrm{P}<0.01,{ }^{\Delta \Delta \Delta} \mathrm{P}<0.001$ compared to (A) human PYY(1-36) or (C) $16.7 \mathrm{mM}$ glucose plus $10 \mathrm{mM}$ alanine.

Figure 2. Effects of PYY(1-36) peptides on (A,B) protection against cytokine-induced apoptosis and (C-E) beta-cell proliferation. (A) BRIN-BD11 and (B) 1.1 B4 beta-cells were cultured (16 h) with PYY peptides or GLP-1 $\left(10^{-8}\right.$ and $\left.10^{-6} \mathrm{M}\right)$ in the presence of a cytokine cocktail and apoptosis detected using the TUNEL assay. (C) BRIN-BD11, (D) 1.1B4 and (E) INS1 832/13, as well as Npy1r or Npy2r KO INS1 832/13, beta-cells were cultured (16 h) with PYY peptides or GLP-1 (10-8 and $\left.10^{-6} \mathrm{M}\right)$ and proliferation assessed by Ki-67 staining. All values are mean $\pm \operatorname{SEM}(\mathrm{n}=3)$. $(\mathrm{A}, \mathrm{B}) * \mathrm{P}<0.05$, $* * \mathrm{P}<0.01$, *** $\mathrm{P}<0.001$ compared to cytokinecocktail. ${ }^{\Delta \Delta} \mathrm{P}<0.01,{ }^{\Delta \Delta} \mathrm{P}<0.001$ compared to RPMI media control. (C-E) $* \mathrm{P}<0.05,{ }^{* *} \mathrm{P}<0.01$, *** $\mathrm{P}<0.001$ compared to RPMI media control. ${ }^{\Delta} \mathrm{P}<0.05,{ }^{\Delta \Delta \Delta} \mathrm{P}<0.001$ compared to unaltered INS1 832/13 wild-type cells at each condition. Representative images for each treatment are provided in the supplementary data.

Figure 3. Effects of PYY(1-36) peptides on (A) food intake and (B) glucose tolerance and insulin secretion in overnight fasted mice. (A) Cumulative food intake was assessed after i.p. 
administration of saline vehicle $(0.9 \% \mathrm{NaCl})$ or in combination with PYY(1-36) peptides (25 $\mathrm{nmol} / \mathrm{kg}$ bw). (B) Blood glucose and (C) plasma insulin levels were assessed immediately prior to, and at regular intervals subsequent to, i.p. injection of PYY(1-36) peptides (each at 25 $\mathrm{nmol} / \mathrm{kg}$ bw dose) in combination with glucose (18 mmol/kg bw). Respective areas under the curve are shown in the insets. All values are mean $\pm \operatorname{SEM}(\mathrm{n}=6) .{ }^{*} \mathrm{P}<0.05,{ }^{*} * \mathrm{P}<0.01$ compared to saline control. ${ }^{\Delta} \mathrm{P}<0.05,{ }^{\Delta \Delta} \mathrm{P}<0.01,{ }^{\Delta \Delta} \mathrm{P}<0.001$ compared to human $\mathrm{PYY}(1-36)$.

Figure 4. Effects of sea lamprey and sturgeon PYY(1-36) on (A) body weight, (B) \% body weight reduction, (C) food and (D) fluid intake, non-fasting (E) blood glucose as well as plasma (F) insulin and (G) glucagon in STZ-induced diabetic mice. (A,C-F) Parameters were measured at regular intervals for 3 days before and 21 days during treatment with twicedaily injection of sea lamprey and sturgeon PYY(1-36) (both peptides at $25 \mathrm{nmol} / \mathrm{kg} \mathrm{bw}$ ) in STZ-induced diabetic mice. (B,G) Parameters were measured on day 21. All values are expressed as mean \pm SEM for 6 mice. $* \mathrm{P}<0.05, * * \mathrm{P}<0.01, * * * \mathrm{P}<0.001$ compared with $\mathrm{STZ}$ diabetic control mice. ${ }^{\Delta} \mathrm{P}<0.05,{ }^{\Delta \Delta} \mathrm{P}<0.01$ and ${ }^{\Delta \Delta \Delta} \mathrm{P}<0.001$ compared with lean control mice.

Figure 5. Effects of sea lamprey and sturgeon PYY(1-36) on (A,B) glucose tolerance, (C) peripheral insulin sensitivity as well as pancreatic (D) insulin and (E) glucagon content in STZ-induced diabetic mice. Parameters were measured at after 21 days during treatment with twice-daily injection of sea lamprey and sturgeon PYY(1-36) (both peptides at $25 \mathrm{nmol} / \mathrm{kg}$ bw) in STZ-induced diabetic mice. (A) Blood glucose and (B) plasma insulin were measured prior to and after i.p. administration of glucose alone $(18 \mathrm{mmol} / \mathrm{kg})$ at $\mathrm{t}=0 \mathrm{~min}$. (C) Blood glucose 
was measured after i.p. administration of insulin $(25 \mathrm{U} / \mathrm{kg} \mathrm{bw})$ at $\mathrm{t}=0 \mathrm{~min}$. (A-C) AUC data is shown in insets. (D,E) Pancreatic insulin and glucagon content was measured by RIA or ELISA, respectively, following acid-ethanol extraction. All values are expressed as mean \pm SEM for 6 mice. ${ }^{*} \mathrm{P}<0.05,{ }^{* *} \mathrm{P}<0.01,{ }^{* * *} \mathrm{P}<0.001$ compared with STZ diabetic control mice.

Figure 6. Effects of sea lamprey and sturgeon PYY(1-36) on pancreatic morphology in STZ-induced diabetic mice. Parameters were measured after 21 days during treatment with twice-daily injection of sea lamprey and sturgeon PYY(1-36) (both peptides at $25 \mathrm{nmol} / \mathrm{kg}$ bw) in STZ-induced diabetic mice. (A-E) Representative images of islets showing insulin (red) and glucagon (green) immunoreactivity from each treatment group. (F) \% centrally located alphacells, (G) numbers of islets $/ \mathrm{mm}^{2},(\mathrm{H})$ total islet area, percentage (I) alpha- and (J) beta-cell area as well as proliferating $(\mathrm{K}, \mathrm{M})$ and apoptotic $(\mathrm{L}, \mathrm{O})$ alpha- or beta-cells, as appropriate. All values are expressed as mean $\pm \mathrm{SEM}$ for 6 mice. ${ }^{*} \mathrm{P}<0.05, * * \mathrm{P}<0.01,{ }^{*} * \mathrm{P}<0.001$ compared with STZ diabetic control mice. ${ }^{\Delta} \mathrm{P}<0.05,{ }^{\Delta \Delta} \mathrm{P}<0.01$ and ${ }^{\Delta \Delta \Delta} \mathrm{P}<0.001$ compared with lean control mice. Representative images of insulin and glucagon positive cells, co-stained with Ki-67 or TUNEL, for each treatment group are provided in the supplementary data. 

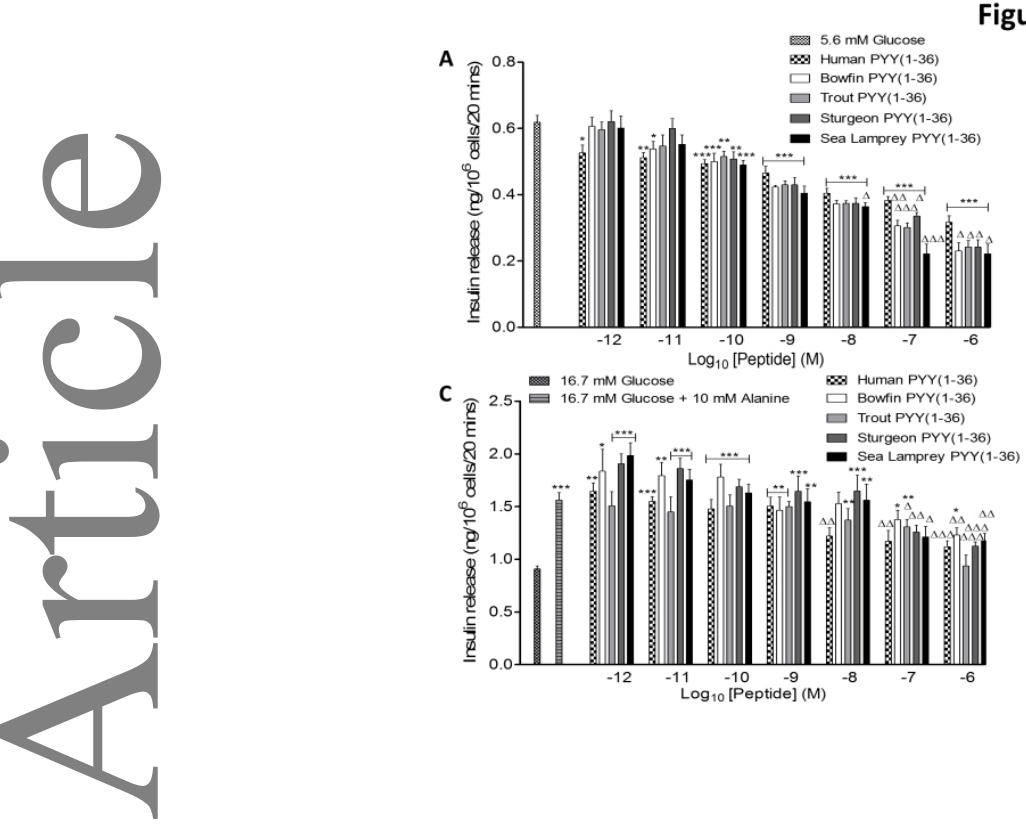

Figure 1
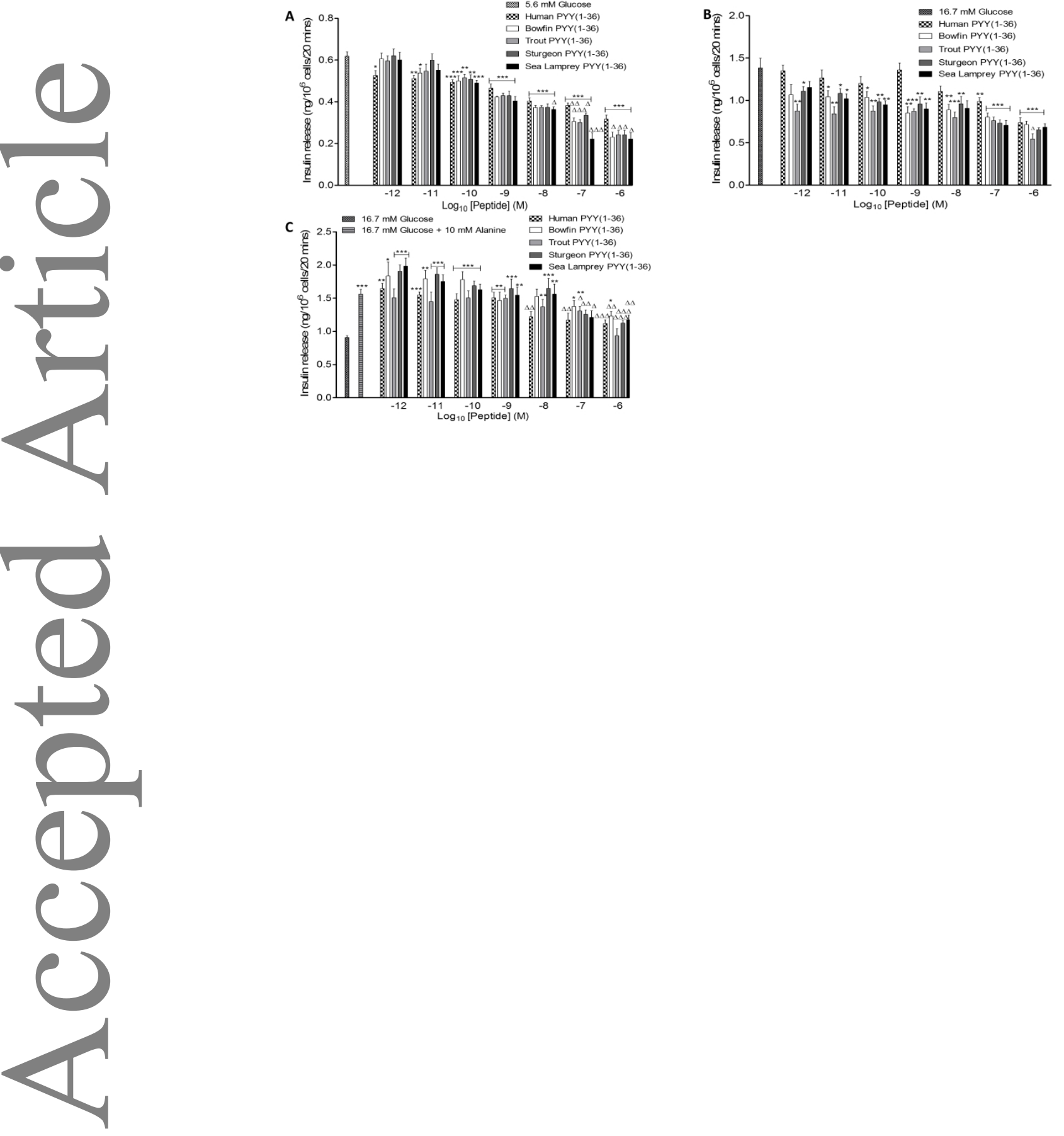

This article is protected by copyright. All rights reserved. 
Figure 3

A

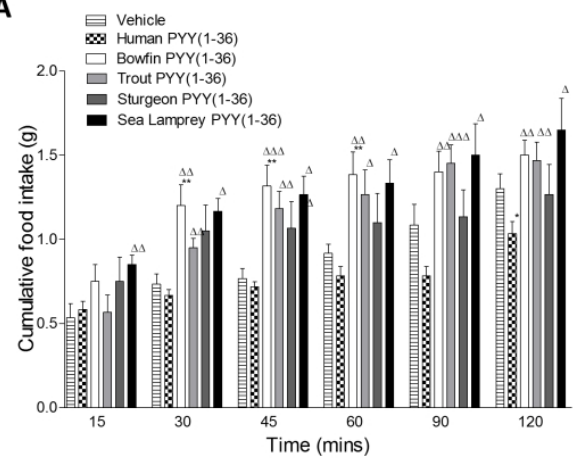

B

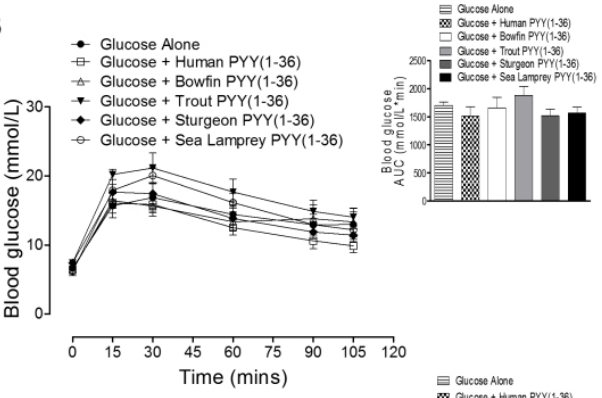

C

- Glucose Alone

* Glucose + Human PYY(1-36)
$*$ Glucose + Bowfin PYY (1-36)

- Glucose + Sturgeon PYYY1-3

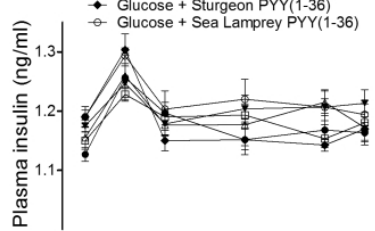

2010 .

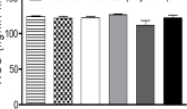

C

\begin{tabular}{lllllllll}
\hline 0 & 15 & 30 & 45 & 60 & 75 & 90 & 105 & 120 \\
Time (mins)
\end{tabular}

This article is protected by copyright. All rights reserved. 
Figure 4
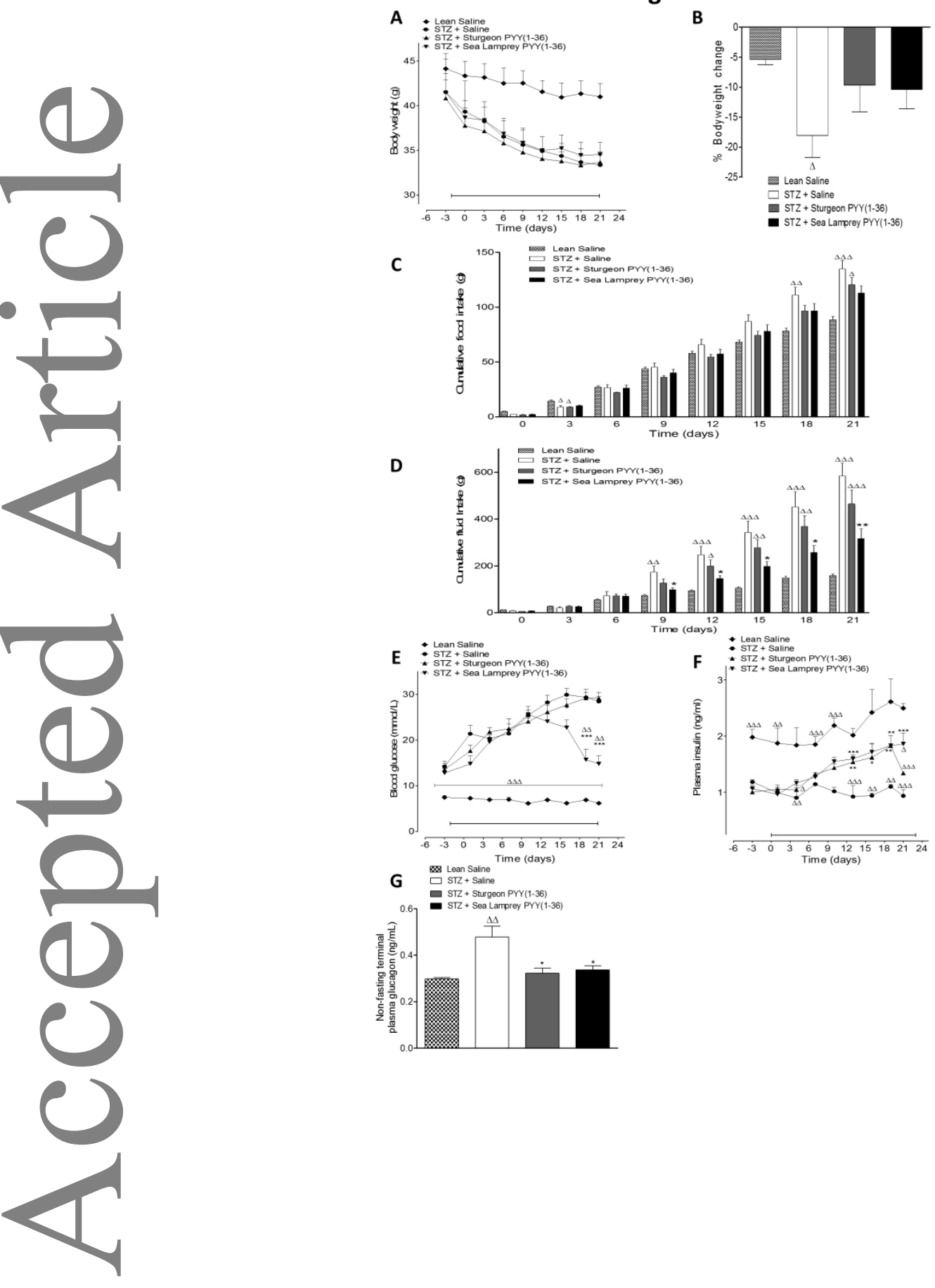

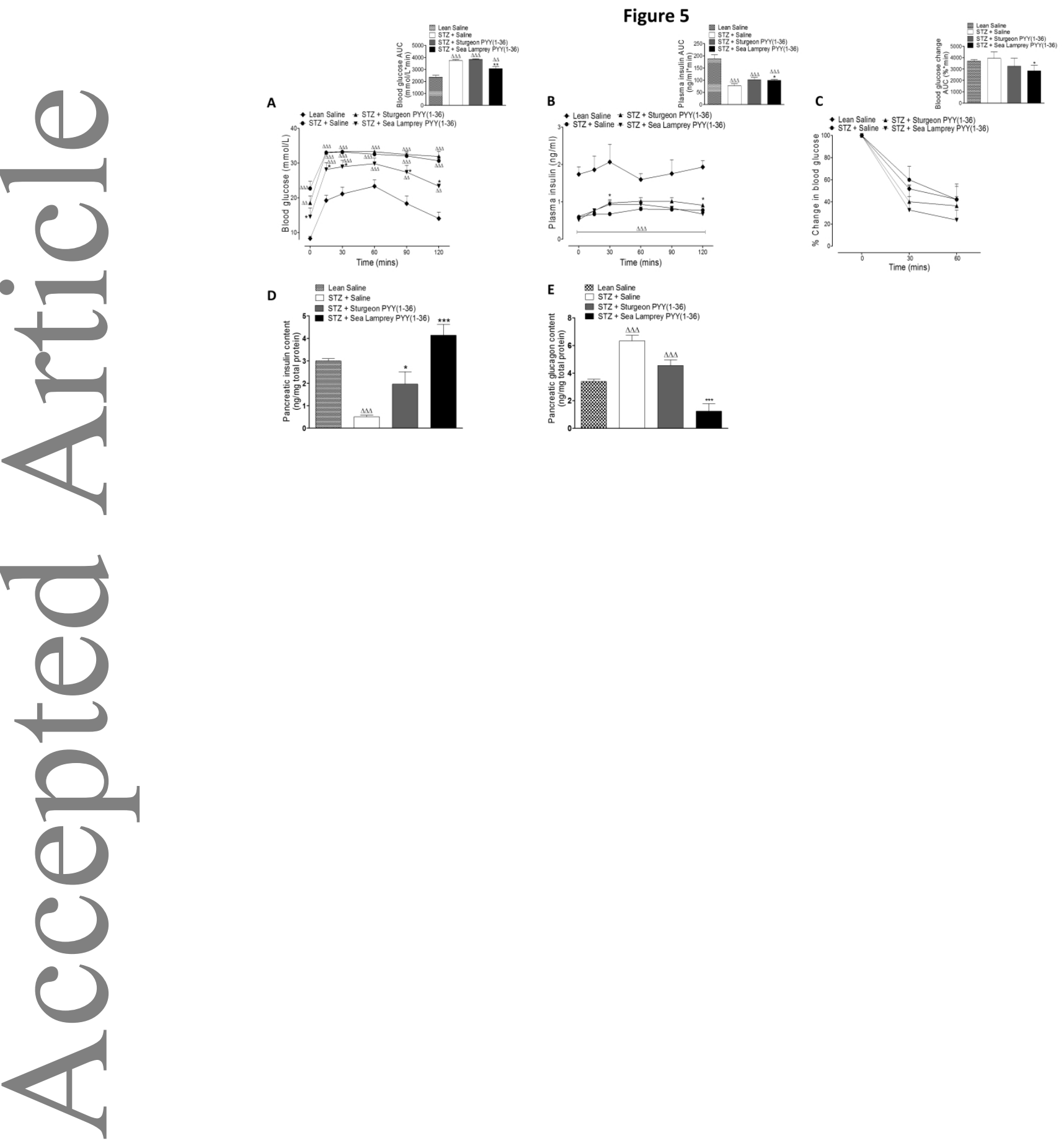


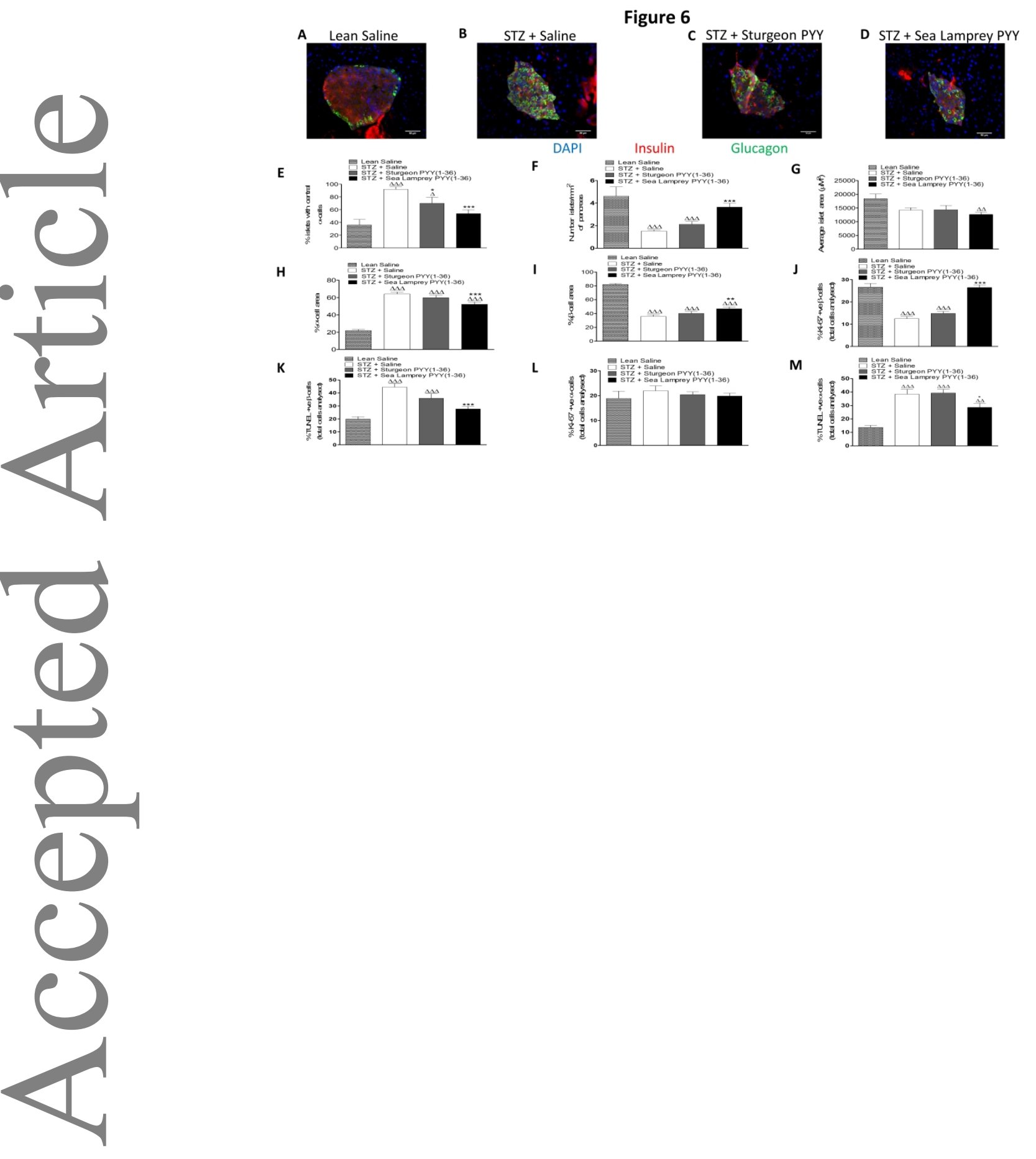

